\title{
NAIADITES ELONGATUS DAWSON, 1860 (LAMELLIBRANCHIA): PROPOSED SUPPRESSION UNDER THE PLENARY POWERS AS A NOMEN DUBIUM Z.N.(S.) 1604
}

\section{By M. J. Rogers (21, Canynge Square, Clifton, Bristol 8, England)}

The purpose of the present application is to request the suppression of the binomen Naiadites elongatus Dawson. The case is one in which the original figure and description are inadequate; the type material is indeterminate and secondary types belong to several genera. Accurate definition of the species is therefore impossible. The facts of the case are stated below.

2. J. W. Dawson (1860, Supplement to "Acadian Geology": 44) first described his species Naiadites elongata (sic) as follows: "Smaller than the preceding [Naiadites carbonarius], and more elongated laterally; the beaks obtuse and more anterior [but see 6 below]; the hinge-line nearly straight and less than half the length; ventral margin slightly compressed; length about half an inch; common at the Joggins and Sydney [Nova Scotia], in the middle coal-measures. See Fig. 23, in paper above cited." [Dawson, 1854, Quart. J. Geol. Soc. London $10: 39$ ]. The shell Dawson figured in 1854 as Modiola cannot now be identified, but in 1894 (Canadian Record of Science 5 : 125) he stated that it belongs to his new species Naiadites mytiloides.

3. In 1863, J. W. Salter (Quart. J. Geol. Soc. London $19: 79$, fig. 1) figured as Anthracomya elongta, at natural size and also much enlarged, a right valve sent to him by Dawson from the Coal Measures of Nova Scotia. According to a label in the British Museum (Natural History), the shell figured by Salter lies on a piece of shale from Sydney, Cape Breton Island, Nova Scotia, L. 14992, but no specimen on the shale closely resembles Salter's figure. The only fossil which Salter's figure might be intended to represent is now referred to Anthraconauta cf. phillipsii (Williamson, 1836).

4. Dawson, in 1868 ("Acadian Geology" (ed. 2) : 204), repeated his 1860 description using the binomen Naiadites (Anthracomya) elongata, adding that the species might attain a length of one inch. A figure (43) was added of a right valve, at natural size and also much enlarged. These figures resemble Salter's, but show a different interpretation of the posterodorsal margin. Dawson's figures do not closely resemble any specimen in the Redpath Museum, Montreal, nor in the British Museum (Natural History), although it may have been intended to represent B.M. L. 14992 (see 3 above).

5. In 1894 (Canadian Record of Science 5 : 126-7, figs. 6-8) Dawson transferred his species elongata to the genus Anthracomya, redefining it as follows: "Obliquely ovate form, the length in typical specimens being about double the breadth. The umbones are somewhat elevated and near the narrower anterior end. The straight hinge-line is somewhat oblique and a little more than onethird of the length of the shell. The front margin is slightly sinuated, the posterior margin regularly rounded. The surface is smooth and shining, with concentric lines of growth. This is by much the most abundant species, and is 
very varied in form and size. When aged, it is more elongated than when immature, and the hinge-line relatively shorter and less elevated." The localities given were South Joggins, Pictou, Sydney, Glace Bay, Mabou, Riversdale, Swan Creek and Parrsboro, horizons at the last three localities being low in the system, and the fossils being small in size. Figure 6 which accompanied this description is the same as the 1868 figure (see 4 above). Figure 8 inaccurately represents Redpath Museum specimen No. 2,1166, a whitened fossil labelled plesiotype from the Coal Formation of the Middle Carboniferous at Joggins. A Note on the reverse of the mounting card stated that it is the original of "C.R.S. p. 126, fig. 8" and the spirorbid on the upper posterior margin of the specimen is shown in Dawson's figure. This shell is now referred to Naiadites longus Dawson, 1894. Figure 7 is probably a rather inaccurate representation of Redpath Museum specimen No. 2,1167. This shell is whitened and the label in the handwriting of Dawson's assistant, Ardley, states that it is a co-type of Anthracomya elongata (Dawson), from Sydney, Cape Breton Island, Nova Scotia. This specimen is now referred to Anthraconauta phillipsii (Williamson).

6. Dawson sent some of his Nova Scotian Upper Carboniferous lamellibranch material to Wheelton Hind for comment. Accordingly, in 1894 (Quart. J. Geol. Soc. London $50: 440$ ) Hind said: “It is very difficult to be absolutely sure as to the generic position of the shells figured as Anthracomya elongata, as there are no specimens showing the hinge-line, ligament, or musclescars, but from the shape they possibly belong to this group. There is nothing to add to the original description, but $I$ think that the sentence describing the position of the umbones is misleading. It says, "the beaks obtuse and more anterior ', but it is difficult to see what is the meaning of the word more. ${ }^{1}$

"There appear to have been two forms of varieties of this shell, one more elongate and comparatively narrower, the other short and as broad as long."

Hind gave five illustrations of the species in this paper, one (Pl. XX, fig. 1la) representing Redpath Museum specimen No. 2,1164b from Mabou which is now referred to Anthraconauta cf. phillipsii (Williamson). The other four figures (Pl. XX, figs. 7-10) represent fossils on a piece of silstone, British Museum (Natural History) No. L. 47795, which is from South Joggins, according to the Museum label; but another label, stuck on the matrix, gives the locality as Pictou. Numbers 7 and 9 on L. 47795 are now referred to Curvirimula (?) ovalis (Dawson, 1860) (L. 47795.7 is identified from Hind's figure, since the fossil is now lost); L. 47795.8 is referred to Naiadites sp. and L. 47795.10 is identified as Curvirimula (?) corvosa sp. nov. (Rogers, M. S.).

7. Morningstar (1922, "Pottsville Fauna of Ohio ", Bull. Geol. Surv. Ohio $25: 220-1)$ described shells from the Lower Pottsville as Naiadites elongatus Dawson. Three figures were given (Pl. XII, figs. 7-9). The first two are of flattened shells now referred to Anthraconauta ef. phillipsii (Williamson) (Ohio State University Geological Museum Nos. 15251, 15250); the third (OSUGM No. 15252) is now referred to Naiadites ef. productus (Brown, 1849).

8. The binomen Naiadites elongatus Hind, 1883 was used extensively in the British literature until Trueman and Weir (1956, Pal. Soc. Monograph, Pt. IX,

1 A clerical error for "less". -J. W. D., May, 1894. 
p. 254) pointed out that it was a junior secondary homonym of Naiadites elongatus Dawson, 1860, and they proposed a new name for Hind's species. Hind did not consider that his species was morphically similar to Dawson's.

9. Summarizing: from (2) above it is seen that the original description of Naiadites elongatus Dawson, 1860 was inadequate and referred to a figure of a fossil which was later (see 2) transferred by Dawson himself to a different species. This fossil cannot now be recognized in any Museum collections. Subsequently (1868), on repetition of the original description, a figure was added which may have been intended to represent a shell now considered to be referable (with cautionary " cf." ") to the species Anthraconauta phillipsii (Williamson, 1836). (See 3 and 4 above.) Later (1894), Dawson illustrated a revised description with figures of shells now referred to the genera Anthraconauta and Naiadites (see 5). These facts tend to support Hind's observation that two varieties were suggested, and Dawson's comment that his species is very varied in form (see 5 and 6). It is the present author's contention that the species Naiadites elongatus Dawson, 1860 is not now identifiable.

10. The binomen Naiadites elongatus Dawson has been used occasionally by palaeontologists since Dawson's time, but since it is not now possible to define the species, I ask the International Commission on Zoological Nomenclature :

(1) to use its plenary powers to suppress the specific name elongatus Dawson, 1860, as published in the binomen Naiadites elongatus for the purposes of the Law of Priority but not for those of the Law of Homonymy;

(2) to place the specific name elongatus Dawson, 1860, as published in the binomen Naiadites elongatus on the Official List of Rejected and Invalid Names in Zoology. 


\section{$2 \mathrm{BHL}$ Biodiversity Heritage Library}

Rogers, M J. 1963. "Naiadites elongatus Dawson, 1860 (Lamellibranchia) : proposed suppression under the Plenary Powers as a nomen dubium." The Bulletin of zoological nomenclature 20, 440-442.

https://doi.org/10.5962/bhl.part.6661.

View This Item Online: https://www.biodiversitylibrary.org/item/44462

DOI: https://doi.org/10.5962/bhl.part.6661

Permalink: https://www.biodiversitylibrary.org/partpdf/6661

\section{Holding Institution}

Natural History Museum Library, London

\section{Sponsored by}

Natural History Museum Library, London

\section{Copyright \& Reuse}

Copyright Status: In copyright. Digitized with the permission of the rights holder.

License: http://creativecommons.org/licenses/by-nc-sa/3.0/

Rights: https://biodiversitylibrary.org/permissions

This document was created from content at the Biodiversity Heritage Library, the world's largest open access digital library for biodiversity literature and archives. Visit BHL at https://www.biodiversitylibrary.org. 